\title{
Entry Mode Influence On Strategic Positioning: Analysis Of Two Telephone Operators In Brazil
}

\author{
Fernando Ceragioli \\ Universidade Positivo \\ fernando.ceragioli@bol.com.br/fernando.ceragioli@nsn.com \\ Alexandre Reis Graeml \\ Universidade Positivo / Universidade Tecnológica Federal Do Paraná \\ graeml@fulbrightweb.org/agraeml@up.edu.br
}

\begin{abstract}
This study analyzes the strategies and market positioning adopted by Brasil Telecom (incumbent) and GVT (mirror company) over the last few years. The research involved semi-structured interviews with executives of the two companies, as well as documental analysis, particularly of those companies' annual reports. The data was then confronted with a model that was consolidated by the authors based on previous work by Hrebiniak and Joyce, in 1985, and Hax and Wilde II, in 1996 and 2001. Results show that those organizations make strategic choices and develop organizational competences that are still influenced by the way they entered the market several years ago.
\end{abstract}

KEY WORDS: environmental determinism; strategic choices; strategic positioning; Delta model.

\section{INTRODUCTION}

Distinct administrative and strategic actions can be adopted by organizations to face the challenges imposed by the market, leading to different strategic positioning. As a result of the quality of their choices, organizations may succeed or fail in the marketplace.

Studies by Schumpeter (1934), Burns and Stalker (1961), Woodward (1967), Thompson (1967), Aldrich and Pfeffer (1976), Hannan and Freeman (1977), Pfeffer and Salancik (1978), Hrebiniak and Joyce (1985), Scott (1987), Dimaggio and Powell (1991) and Borenstein (1999), among others, discuss the restrictions imposed by the environment on the organizations' strategic choices.

Telecommunication companies, after privatization, were confronted with a highly regulated environment, facing intense technological changes and resource restrictions that needed to be taken into account in defining their strategic positioning.

There seems to exist a degree of influence of the entry mode of telecommunications' organizations in the Brazilian market and their strategic position- ing, which can be studied by means of models and theories that relate the environmental determinism to strategic choices.

The telecommunications model that was settled in Brazil is, curiously, strongly based on regulatory asymmetries that favor new entrants, as mirror enterprises do not have the same obligations as the concessionaires (incumbents) with respect to tariffs and fees, universalization goals or concerning the adoption of new technologies (MIRA, 2003). This provides even greater relevance to studies that help understand the relationship among environment characteristics and strategic choices made by organizations playing in the telecom market. After all, different players are faced with different competitive conditions, depending on the way they entered the market.

This study aims to explore the preliminary expectations and to help understand whether, in fact, entry mode is an important factor determining the strategic choices and the positioning adopted by telecom companies. That may contribute to a reflection about suitable privatization models. After all, in spite of the inexistence of favorable political conditions for new 
large scale privatization programs, there is still an important sector of the Brazilian economy that is on the government's hands (power generation and distribution), which has some characteristics that are similar to those of the telecommunications' industry.

\section{THEORETICAL FRAMEWORK}

The theoretical framework for this study is based on two different perspectives: (1) an environmental one, characterized by the dichotomy environmental determinism/strategic choices and (2) a strategic positioning one.

\section{Environmental determinism versus strategic choice}

According to Hrebiniak and Joyce (1985), the existing literature prior to their study separated strategic choice and environmental determinism, considering the two perspectives to be mutually exclusive and even antagonic, with respect to the possibility of application to the organizational environment. Most authors acknowledged, however, that different degrees of choice or determinism could happen, which allowed Hrebiniak and Joyce (1985) to create a typology to explain organizational adaptation based on the interaction between those two variables.

Their framework presented the two variables as being orthogonal, generating four quadrants for adaptation and strategic positioning: 1) natural selection - with minimum choice possibilities, and the organizations either adapting or being excluded; 2 ) differentiation with a high level of determinism and adaptation possible with restrictions; 3 ) strategic choice - with maximum choice and adaptation based on planning; and 4) choice without differentiation - with incremental choice and adaptation happening by luck.

Hrebiniak and Joyce's (1985) framework is shown in Figure 1. Strategic choices and environmental determinism are represented there by means of two axes with scales from low to high. The quadrants help defining the domain and the maneuvering freedom the organization has in its environment.

Most authors that discuss adaptation focus their efforts in understanding quadrant I (natural selection) and III (strategic choice), being the two other quadrants' possibilities neglected, as noted by Hrebiniak and Joyce (1985).

The choice-determinism typology allows for an evaluation of the quantity and type of strategic choices available to an organization, the emphasis on decisions (focused on means or ends), the political behav- ior of those involved, the conflicts and search activities performed by organizations in their environment (HREBINIAK and JOYCE, 1985).

Figure 1 - Strategic choices and environmental determinism

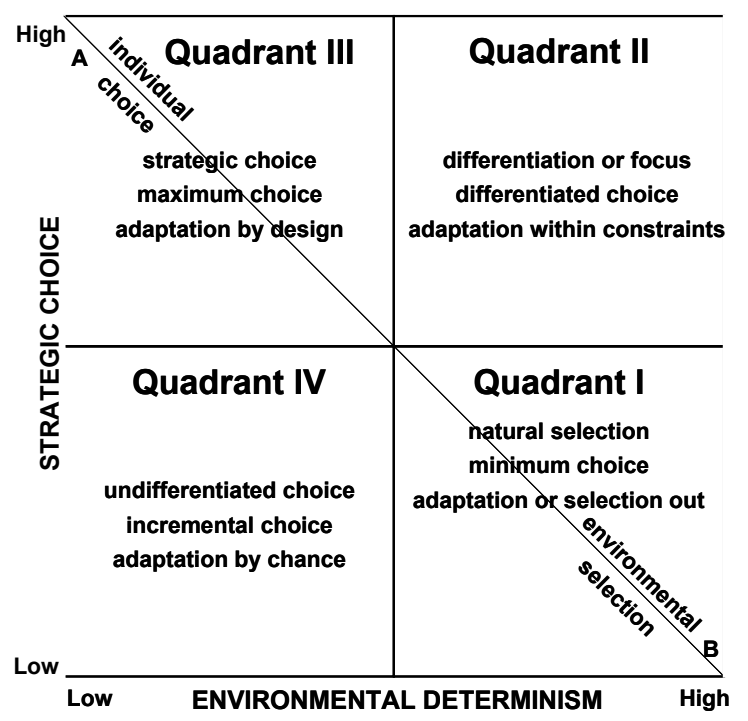

Source: Hrebiniak and Joyce (1985).

\section{Strategic positioning}

The reasons Porter (1986) gives us for adopting a strategy relate to two different perspectives: attempt to achieve leadership in the market due to low costs or product differentiation. Treacy and Wiersema (1995), on their turn, consider that there are "value disciplines". In their studies they consider Porter's perspectives but add a third one, focusing on solutions to the customers.

Another different perspective arises from Hax and Wilde II's (2001) Delta model, which consists on a tripod for strategic positioning that takes into account Porter's and Treacy and Wiersema's contributions, adding lock in to the lot.

\section{Delta model}

The Delta model deals with strategic features concerning the practical analysis of organizations that were successful in each of the strategic options defined in it. The Delta model recommends answers to be found for the following questions: What is the strategy's main purpose? What are the suitable means to reach it?

Answers to such questions relate to three strategy dogmas (HAX, 1996), which define the way an organiza- 
tion should behave in order to succeed in the market, regardless of its strategic choices. The first dogma is "creation of economic value": to achieve superior and sustainable performance, measured in terms of profitability in the long run. The second dogma involves "the creation of a customer proposition involving unique value", which basically means attracting, satisfying and retaining customers. The third dogma is "the creation of success spirit", by involving talents and networking, i.e., attracting, satisfying and retaining the best workers (talents), in order to obtain and keep a competitive edge. The three dogmas define the purpose of strategy and the means to achieve it.

The first reflection that happens in the process of defining the strategy for an organization or business involves deciding how relevant the adopted positioning is. That represents an attempt to capture the essence of how an organization competes in its main market or, in other words, how a company decides to attract, satisfy and retain its customers (HAX and WILDE II, 2001).

Conceptually, there are three distinct strategies acknowledged in Hax and Wilde II's (2001) model. Each of them involves a different way of achieving leadership in the market. Graphically, these three alternatives are represented as the edges of a triangle, which represent the starting point for the development of a strategic vision. Although, in practice, most organizations find themselves in a hybrid situation (see Figure 2 ), it is useful to reflect about those alternatives as if they were mutually exclusive, and completely different approaches around which to organize a business.

The strategies related to the edges of the triangle in the Delta model are: a. best product - it represents the classical way of facing competition, where a consumer is attracted by the inherent characteristics of the company's product, e.g., the lowest price or a distinctive feature, for which the customer is willing to pay a premium price. Such products tend to be standardized and sold as packages.

b. total customer solution - non standardized product or service, where the customer depends on the organization for adjustments. The organization tries to understand the customer's needs and develops a relationship with the customer that adds value to the business with each individual customer. Instead of presenting standard products to the market, the organization makes an effort to provide a set of products and services that can be adjusted to fit the customer's needs, so that value can be specifically created for each of its customers.

c. system lock-in - the strategy based on system lockin has a broader scope, including the company itself and other organizations, such as its customers and suppliers and providers of complementary products and services. Complementary products or systems are provided by companies that add value to the original proposition of an organization. This strategy involves identifying, attracting and leveraging the efforts of these third parties, whose products and services help to improve the organization's strategic positioning in the market.

The Delta model is used to represent the strategic positioning of organizations. Figure 2 shows it being used to analyze the strategies of companies playing in different markets.

Figure 2 - Strategic positioning

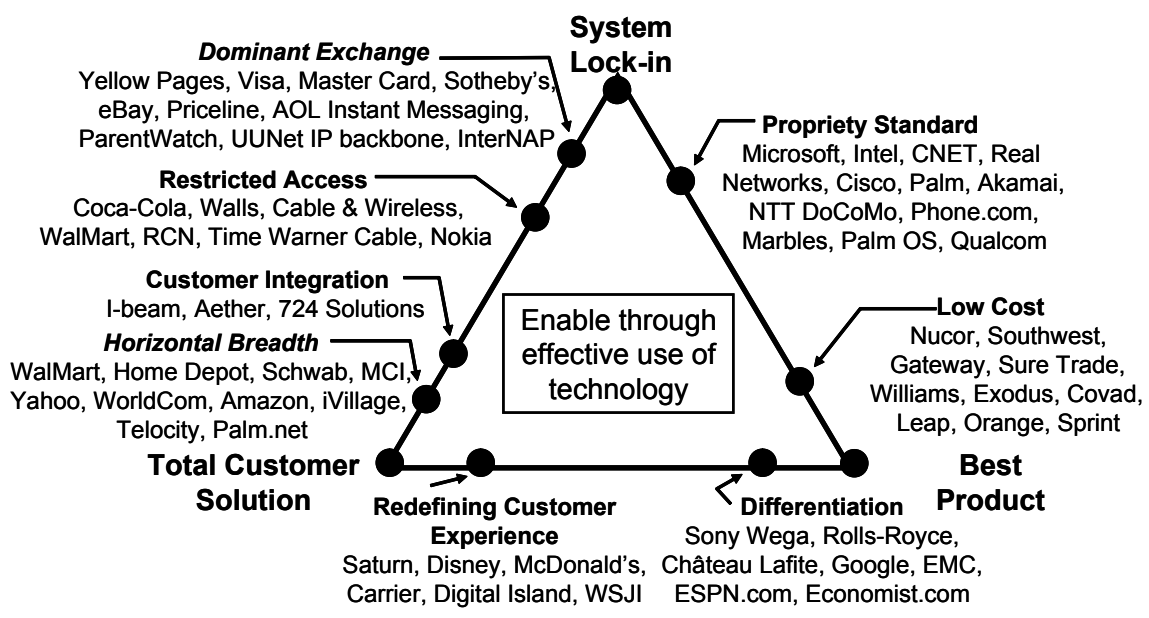

Source: adapted from Hax and Wilde II (2001). 


\section{METHODOLOGY}

Data was gathered by means of case studies, with a primarily descriptive intent. The authors, however, also use their findings to explain things, trying not only to identify the existence of the relationship between the studied phenomenon and a model, but also to determine the nature of such relationship.

The level of analysis adopted in the case studies was organizational and the unit of analysis was their executives (directors and managers) with involvement with the organizations' strategic planning.

A set of questions was prepared to help on the interviews with the executives, who were visited in their work environment most of the times or, when that was not possible, were interviewed via telephone.

The nature of the study was theoretical-empirical, because it was not based only on previous works but relied also on field research that involved the interviews mentioned above and documental analysis of the annual reports prepared by the studied organizations and Anatel. The following documents were considered: Anatel (1999), Anatel (2000), Anatel (2001), Anatel (2003), Anatel (2005), Anatel (2006), BrT (1999), BrT (2000), BrT (2001), BrT (2002), BrT (2003), BrT (2004), BrT (2005), BrT (2006), GVT (2004), GVT (2005), GVT (2006), GVT (2006b) and GVT (2007).

The case studies included Brasil Telecom and GVT - Global Village Telecom - and involved executives that took part in the implementation of the those companies' strategies.

These two companies were chosen because they entered the telecommunications market in very distinct ways, which facilitates contrasting them: Brasil Telecom took over the state owned company that had the monopoly of telecommunications services in the regions where it operated. GVT was granted an authorization to operate in the same geographic areas, with the purpose of generating competition and providing an alternative to Brasil Telecom's services. Brasil Telecom inherited a huge installed park of equipment and a consolidated network of users, while GVT had to start from scratch.

Another reason for choosing these organizations was the researchers' convenience: they live in the city where those companies have their headquarters or at least important operations, which made it easier for the researchers to carry out the interviews without the need of travelling.
For Brasil Telecom two directors, two managers and two ex-directors of different areas were interviewed. The experience of the participants in the telecommunications industry varied from 25 to 35 years, with an average of 31.5 years.

For GVT, the group of executives that were interviewed took part not only in the execution of the strategy, but also in its development, beforehand. From the fourteen top-management executives of the organization, six were interviewed specifically for this study. The experience of participants in the telecommunications' industry varied from seven to twenty years, with an average of 11.5 years.

The identity of the participants will not be revealed in this paper due to privacy and confidentiality reasons.

The interviews followed a semi-structured script that was previously established, which contained some general questions but was flexible to allow the inclusion of new questions that the researchers found to be relevant at the moment of their contact with the participants (LAKATOS and MARCONI, 2001). This technique allows for important information to be gathered even when not planned at the time the script was created. At the same time, it ensures that the interview does not happen in an uncontrolled way, which would make it difficult to compare and triangulate data at the analysis stage. Following a script allows for data from different participants to be compared with some level of quantification, which was done in this case only with the purpose of better supporting the qualitative findings of the study.

The technique that was used to analyze the interviews, after transcription, involved reading the whole text and highlighting the issues that were important for the argumentation and interpretation. The analysis followed Lakatos and Marconi's (1991) recommendation of adopting three stages for the interpretation of a text or interview: 1 - analysis of the elements; 2 - analysis of the relationships; and 3 analysis of the structure.

The model that was presented by Hrebiniak and Joyce (1985), which relates environment and strategy was combined with Hax and Wilde II's (2001) model, which presents an analysis perspective that is specially useful for IT and telecommunications companies. From the combination of the two models, a macromodel was generated that was adopted to analyze the collected data, as reported in the next section. 


\section{PRESENTATION AND ANALYSIS OF THE RE- SULTS}

\section{Brasil Telecom}

Environmental determinism was considered high since Brasil Telecom entered the market, but the determining factors changed over time. From 1998 to 2003 the restrictions imposed by Anatel were more important than today, mainly because of the service universalization goals. Nowadays, after the goals have already been accomplished, the regulating agency appears only as a restriction to the exploration of new services.

The relationship with suppliers changed over time. In the first few years, the suppliers had strong bargaining power because the operators were all being pressured to fulfill their obligations with the regulating agency, with respect to the expansion of their networks. That generated competition for resources, which became scarce. However, the suppliers lost power and stopped being a significant restriction when the rhythm of expansion of the sector decreased, after the demands imposed on concessionaires and authorized companies were fulfilled.

Competition became more intense recently, mainly with respect to richer customers. When Brasil Telecom started operating, the company practically didn't face any competition, but today it needs to take other players' moves into account in order to determine its own strategy.

Another relevant factor in Brasil Telecom's changing scenario over time was the financial restriction faced by the organization due to the high cost of capital to finance the company's investments. Interests became very expensive, at a stage.

The freedom for Brasil Telecom's strategic choices was considered average to high, in the analysis that was performed using the reference macro-model, and it changed with time. Primary data were essential for the understanding of the choices that were made by the company, after privatization. However, secondary data were the main sources to help understand the number of strategic choices that are available to Brasil Telecom more recently.

The same way the relationship with the environment was changing with time, there were also changes in strategy from the time the company entered the market until today.
Brasil Telecom has been in quadrant II of Hrebiniak and Joyce's (1985) model, where there is high environmental determinism and average to high degree of freedom for strategic choices. As a consequence of changes in the environment and of the flexibility of strategic choices over time, some participants even argued that Brasil Telecom was moving to quadrant III. This would be the result of a reduction of the restriction imposed by the suppliers, Anatel and the competition. But, after the company started facing competition from paid TV players in the telecommunications market, the dispute for the market became fiercer, and Anatel started being perceived as a restrictive agency also for imposing limits to the company's intention to explore new services and markets. One of Brasil Telecom's strategies became trying to convince Anatel that changes were needed in the legislation to prevent newcomers from entering markets that traditionally belonged to telecommunications companies.

With respect to its strategic positioning, Brasil Telecom first positioned itself as a provider of the best product, also putting some effort into building lock-in relationships with the customers, considering that there was no competition prior to GVT spreading its network (which is still not available in many locations) and before other concessionaires could fulfill the goals established by Anatel for their own geographic regions, as they would only be given permission to operate in different areas after meeting the regulating agency's targets for the regions they had been previously assigned. This positioning is still in place for locations where the company does not face direct competition. Figure 3 illustrates the initial strategic positioning by means of arrows that originate in distinct points of quadrant III and point to a positioning in the lower right corner of Hax and Wilde II's triangle. The second and third strategic positioning movements of Brasil Telecom were a result of the competition it started experiencing in its markets. Brasil Telecom tried different strategies that could lead it to benefit from market segmentation. Also in Figure 3 it is shown that, after 2003 and until 2006, with Brasil Telecom's movement within quadrant II, additional strategic positioning efforts took place, focusing on solutions for the customer and differentiation.

The analysis of secondary data (reports issued by the company) supports the results obtained from the analysis of the interviews. One realizes that Brasil Telecom's strategic choices over time evolved in a complex and multi-objective way. 
Figure 3 - Result of the analysis for Brasil Telecom

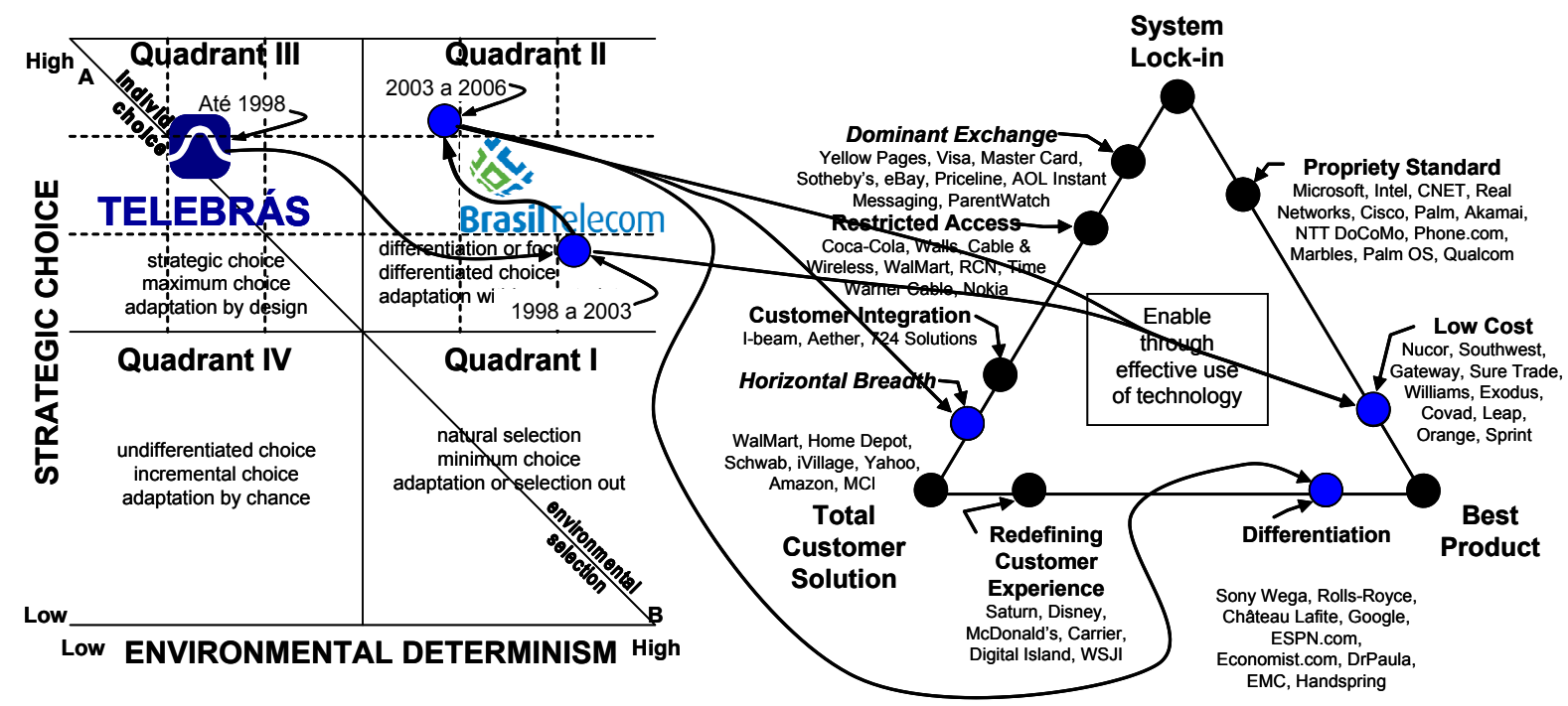

Source: elaborated by the authors, based on the models that inspired the analysis

\section{GVT}

For GVT, environmental determinism appears in the analysis of the primary and secondary data, mainly as a result of the restrictions imposed by the regulating agency and the competition in the market. Financial limitations and the lack of human resources were also reported by interviewed executives, although no evidence of that was found in the reports to which the researchers had access.

There was high availability of strategic choices, since the beginning of the company's operation, which was highlighted by the executives. Participants unanimously stated that GVT had many alternatives from which to choose after a detailed analysis of the market and having had the support of an external consulting company. The universe of mirror companies was also analyzed by the authors of this paper, based on secondary data readily available in the specialized media, and it was noticed that they all had plenty of strategic choices. That becomes clear when one examines each of the mirror companies' positioning, they all adopted very distinct strategies, benefitting from the fact that the restrictions imposed by the regulating agency were lighter to the authorized companies (mirror) than to the concessionaires (incumbents).

GVT's strategic positioning was based on differentiation (attempt to provide the best product), focusing on niche markets where the company could offer technologically superior, high quality, product packages that could make customers loyal, also at lower prices than the competition. Those factors were noticeable in the interviews but also in the analysis of secondary data. There was no evidence of the adoption of a strategy aiming at locking the customers in. Some participants even mentioned that the company offered a "solution for the customer", but that impression was not supported by secondary data, neither by the justification given by the participants for that perception, which reinforced the idea that the company was really focused on a best product strategy.

Secondary data complemented the primary data obtained in the interviews to help placing GVT at the position indicated by the orange dot, in quadrant II of the macro-model (see Figure 4). In an environment of high environmental determinism, which provided flexibility for strategic choices, GVT adopted a differentiation strategy, offering what it considered to be the best product. 
Figure 4 - Result of the analysis for GVT

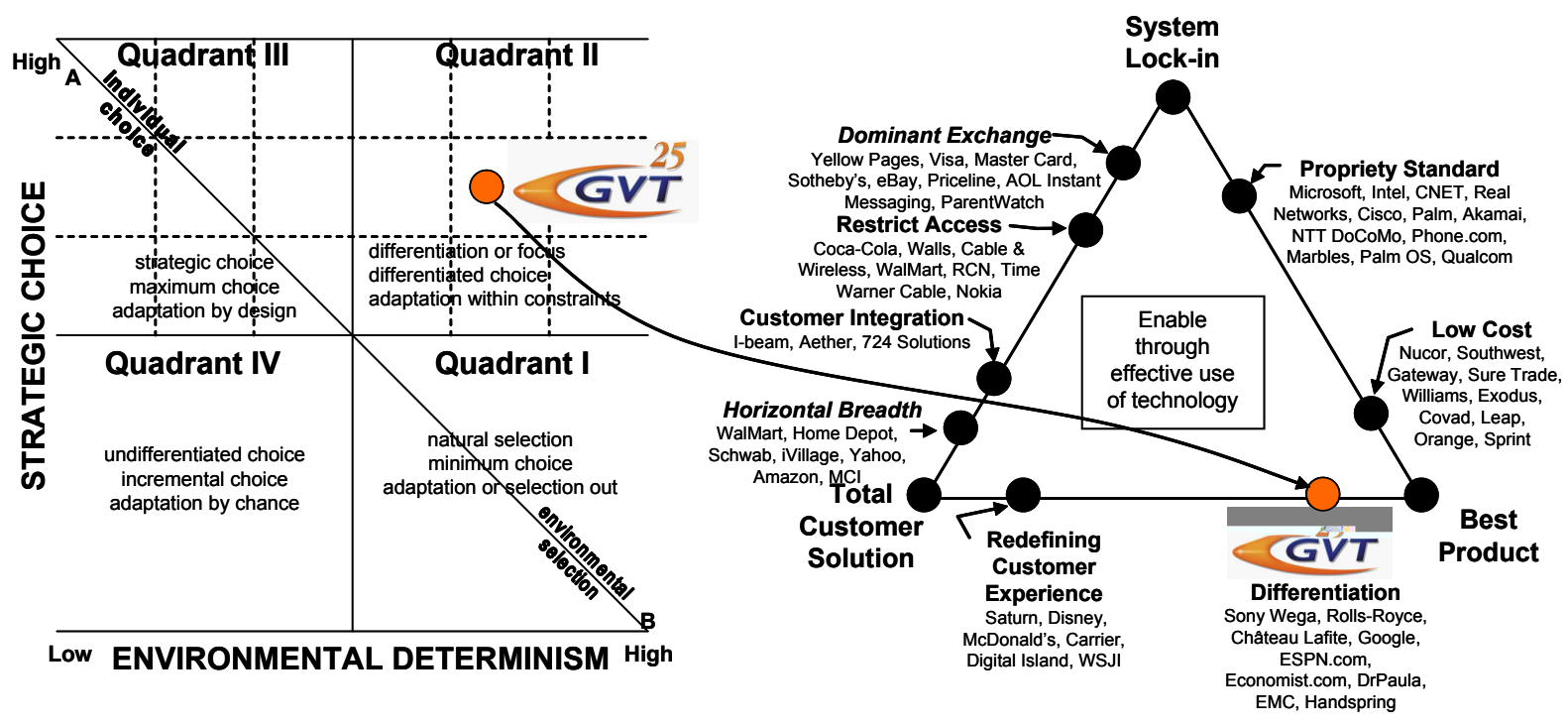

Source: elaborated by the authors, based on the models that inspired the analysis

\section{COMPARATIVE ANALYSIS OF THE RESULTS FOR BRASIL TELECOM AND GVT}

The entry mode influenced and still influences the way the studied organizations perceive the environment in which they play and the strategies they develop to achieve their goals. Consequently, it influences their strategic positioning and the organizational competences they explore and emphasize.

In spite of their activities being regulated and subject to high environmental determinism, the studied organizations also perceive a high level of freedom to choose the means and methods to compete in the market. Such findings are those of typical quadrant II organizations, according to Hrebiniak and Joyce's (1985) model.

The companies' strategic positioning, focused on differentiation and support to niche customers can be easily understood, from the Delta model perspective (Hax and Wilde II, 2001). Decision making about new products and services and about market strategies is very careful, and only takes place after detailed market analysis and pilot testing, taking considerable time until thorough implementation.

Problem solving is very focused on finding specific solutions, as became clear after analyzing the way Brasil Telecom and GVT reacted to a third competitor that started providing paid TV services, in addition to regular telephony and broad band Internet connection. The two companies decided to also find ways to provide that type of service.

Table 1 summarizes and compares the results that were found for Brasil Telecom and GVT, using the macro-model that was created for this study and analyzing the most important variables.

Table 1 - Summary of the results of the analysis of Brasil Telecom and GVT

\begin{tabular}{|l|c|c|c|}
\hline \multirow{2}{*}{ Analyzed items } & \multicolumn{2}{|c|}{ Brasil Telecom } & GVT \\
\cline { 2 - 4 } & $1998-2003$ & $2003-2006$ & 2001-2006 \\
\hline $\begin{array}{l}\text { Freedom to choose } \\
\text { strategies }\end{array}$ & average to high & average to high & high \\
\hline $\begin{array}{l}\text { Environmental } \\
\text { determinism }\end{array}$ & high & high & high \\
\hline
\end{tabular}


Ceragioli, F., Graeml, A. R.: Entry Mode Influence On Strategic Positioning: Analysis Of Two Telephone Operators In Brazil

\begin{tabular}{|c|c|c|c|}
\hline Regulating agency & $\begin{array}{l}\text { high regulation and } \\
\text { high control }\end{array}$ & $\begin{array}{l}\text { high regulation } \\
\text { and low control }\end{array}$ & $\begin{array}{l}\text { high regulation } \\
\text { and low control }\end{array}$ \\
\hline Human resources & no restriction & no restriction & scarce \\
\hline Material resources & scarce & no restriction & no restriction \\
\hline Suppliers & high power & low power & balanced \\
\hline Competitors & low competition & high competition & high competition \\
\hline Financial resources & high cost & high cost & high cost \\
\hline Culture & $\begin{array}{c}\text { restriction to } \\
\text { changes }\end{array}$ & no restriction & no restriction \\
\hline Strategic positioning & $\begin{array}{l}\text { best product } \\
\text { based on broad } \\
\text { availability }\end{array}$ & $\begin{array}{l}\text { best product based } \\
\text { on differentiation }\end{array}$ & $\begin{array}{l}\text { best product based } \\
\text { on differentiation }\end{array}$ \\
\hline
\end{tabular}

Source: the authors.

The results found for the variables discussed above and summarized in Table 1 are typically those of companies that are placed in quadrant II, of Hrebiniak and Joyce's (1985) model.

The studied organizations develop differentiation strategies to avoid becoming commodity sellers, which would lead them to quadrant I. Differentiation happens by means of the provision of packages of products and services that are bundled together in a way it becomes impossible for the customers to compare prices, benefits or costs. If sold alone, those products and services would be easily comparable, and the consumers would probably realize that there was no significant difference among them, which would have lead them to choose the supplier primarily based on price.

It was noticeable that the studied organizations attempt to reduce the environment's influence by means of actions that aim to reduce the restrictions imposed by the regulating agency to their entering new market segments. They also try to eliminate or replace contractual obligations.

The suppliers' power and material resource restrictions were controlled by Brasil Telecom, after a period in which all companies in the market were very concerned about fulfilling the goals that had been established by the regulating agency, which had a high impact on demand and caused the scarce suppliers and resources to be overpriced. GVT, on its turn, has always tried to settle partnerships with its suppliers, so that they finance part of the investments in new infra-structures, which reduced potential problems with suppliers and their bargaining power.
The attempt to develop partnerships in order to increase the provision of services and neutralize the actions of the competition also became evident for Brasil Telecom, after a while, when the company started offering packages that include paid TV to its customers. That was the result of a partnership with Sky, a company that specializes on satellite paid TV services.

Brasil Telecom and GVT struggle to reduce their vulnerabilities in the environment by taking two kinds of actions, which are explained by Hrebiniak and Joyce's (1985) model: (1) actions to differentiate one's products or services, building entrance barriers or eliminating them, and reducing problematic dependency on suppliers or customers; or (2) political actions such as cooperation agreements that have effect on important environmental elements.

Their intent, when they perform such actions, is to reduce the influence of the environment on them so they can move to quadrant III or, at least, prevent moving to quadrant I, which would cause power loss and reduction of achieved advantages. Such actions were not sufficient for the organizations to leave quadrant II, though, in spite of considerable movement inside that quadrant having happened in Brasil Telecom's case, as seen in Figure 3.

Having bought the concession, Brasil Telecom obtained a competitive edge because it was already consolidated in the market with "a working network, excellent cash flow, 100\% of the market at that first moment, an economy of scale and a strong brand" (according to participant $4-\mathrm{BrT}$ ). Of course, some drawbacks were also clearly present: the company was seen as a state owned company (bureaucratized, 
heavy and slow) and had legacy technology, "which did not represent the state-of-the-art in terms of equipment" (according to participant $1-\mathrm{BrT}$ ). The concession's acquisition and the increase of the existing network's capillarity, as a result of regulating pressures and also strategic choices, helped Brasil Telecom to achieve a strategic positioning that was very close to system lock-in, which was not just the result of tariff pressures imposed by Anatel.

Brasil Telecom, which "started with a lot of power" (according to participant $5-\mathrm{BrT}$ ), for being present in the market with a complete installed network infrastructure, trained people, a working operation, on-going cash flow, a strong brand, market scale and $100 \%$ of the wired-telephony market in the region, needed to make an effort to replace the image of a slow and bureaucratic government owned company, by the image of an agile, competitive and quality oriented organization.

The two studied organizations have given little importance to the competition, at the beginning. Brasil Telecom considered GVT a niche organization, with serious difficulty in penetrating Brasil Telecom's markets. GVT thought that its niche market strategy, with differentiated products and a more personalized customer support, could reduce the effects of competition, as it actually happened at first. Nowadays however, both organizations are very concerned with competition because all players are focused on serving the niche of richer customers, since they are the ones that bring the highest return for the investment and are also the ones aimed by indirect competitors, such as mobile phone operators and paid TV.

\section{FINAL CONSIDERATIONS}

This paper has presented the dynamics of the Brazilian (wired-telephony) telecommunications market, which used to be government owned, but was privatized in the late 1990's.

After this sector was privatized, telephone lines, which had been a scarce good for many years in Brazil, became readily available. The quality of telephony services also improved with the privatization of service.

Privatization attempted to bring competition to the telephony market, with the creation of two major categories of organizations: the concessionaires and mirror companies.
A concessionaire (Brasil Telecom) and a mirror company (GVT) that compete in the same region were chosen for this study, with the purpose of understanding the influence of the entry mode in their strategic positioning. In order to do that, a macro-model was conceived, based on Hrebiniak and Joyce's and Hax and Wilde II's models.

The research showed that several factors related to the entry mode influenced and still influence the strategic positioning of the studied organizations, allowing Brasil Telecom to almost lock its customers in, due to the lack of competition in many locations and driving GVT to operate in niche markets.

The two organizations, in spite of operating in the same environment, interpreted and still interpret it differently as a result of entry mode conditions, as it became evident after the interviews and the analysis of the available documental sources.

Brasil Telecom benefitted from the legacy of the government owned company that was privatized, including its network infrastructure and customers. That provided the company with an initial advantage but also imposed on it "liabilities" to be managed, specially the network infrastructure, which is not state-of-the-art equipment, and an organizational culture that used to make sense to the government owned company, but is not suitable to the new scenario. Being a concessionaire, it had to obey to stricter rules, defined by the regulating agency, in comparison to the mirror company. GVT, on the other hand, was created to explore the possibilities of the new deregulated telephony market in Brazil. It started its operation from scratch after been granted an authorization to work as a mirror company for Brasil Telecom.

Brasil Telecom's perception of the market, at the beginning, was one of high determinism, due to the strict control and restrictions imposed by the regulating agency, in addition to the bargaining power of its suppliers. However, the company did not consider that it faced competition and did not feel it had any problem with respect to human resources, at least concerning abilities and competences. It only felt that it needed to change its culture. At the same time, it faced high capital costs that made the necessary investments challenging. The degree of freedom for strategic choices was considered average to high, allowing strategies to be implemented that involved meeting the repressed customer demand and fulfilling the goals imposed by the regulating agency. 
GVT, on its turn, also understood that there was high environmental determinism, as a result of the actions of the regulating agency, which, in spite of exerting low control, imposed restrictions to the exploration of the market. Human resources were scarce, the company perceived competition to be high in the market, but of poor quality and little focus on the customer. The company had a balanced relationship with its suppliers and was pressured by the shareholders to rapidly generate a positive cash flow. Its freedom for strategic choices was considered high, which contributed to its decision to explore market niches, particularly those involving richer customers.

The strategic positioning of both companies was to offer the best product based on differentiation. Both target the niche of richer customers, specially for value-added products and services, where they both faced competition, also from other entrants (paid TV operators) Curiously, their decision to target the richer customers' niche was the result of different strategic views and perceptions of the market.

Differentiation, resulting from such similar products and services, was attempted by offering packages that aggregate products and services, making it difficult for the consumer to directly compare offers.

The organizations try to change their relationship with the environment, avoiding migrating to quadrant I. They do not want the customers to perceive them as commodity sellers, because that would increase the environmental determinism and make it difficult for them to migrate to quadrant III or at least remain in quadrant II.

Changes with respect to the environmental perception are much more explicit for Brasil Telecom, whose relationship with suppliers, its culture, the competition and material resources changed a lot over time, with the organization attempting to move within quadrant II and getting closer to quadrant III.

The studied organizations base their generic strategies in differentiation, with emphasis on efficiency. They are careful in exploring new products and market opportunities, developing previous studies to reduce the risks and applying solutions that address specific problems. This is in agreement with Hrebiniak and Joyce's model, for organizations that play in a scenario of high environmental determinism but with plenty of strategic choices.

Both companies claim that their generic strategy consists on differentiation. In order to reach it, the focus is not on the ends (product or service) but the means to deliver it, i.e., the processes, the strategic partnerships and the supply chain.

The authors of this paper consider that future work could focus on the interaction between environmental determinism and strategic choices, strategic positioning and organizational competence in other industries. This can be particularly useful to help understand how to prepare other sectors that are still under direct control of the government to be privatized when that is considered to be the right thing to do, politically.

\section{REFERENCES}

ALDRICH, Howard. E.; PFEFFER, Jeffrey. Organizations and environments. Annual Review of Sociology, v. 2, p. 79-105, 1976.

ANATEL - Agência Nacional de Telecomunicações. Telefonia fixa [Wired telephony]. 2007. Available at: <http://www.anatel.gov.br>. Access date: 4 Feb, 2009.

ANATEL. Relatório anual Anatel, 1999 a 2006 [Anatel's annual report, 1999 to 2006]. Available at: <http://www.anatel.gov.br/ Portal/exibirPortalInternet.do 2005>. Access date: 4 Feb, 2009.

BORENSTEIN, Carlos Raul; CAMARGO, C. Celso B. Alternativas organizacionais no setor elétrico brasileiro: um instrumento de análise [Organizational alternatives in the Brazilian electricity sector: an analysis instrument]. 1 ed. Porto Alegre: SagraLuzzatto, 1999.

BrT - Brasil Telecom. Relação com investidores [Communication with investors]. 2007. Available at: <http://www.brasiltelecom.com.br/ri/home.do>. Access date: 4 Feb, 2009.

BrT - BRASIL TELECOM. Relatório anual: 1999 a 2006 [Brasil Telecom annual report: 1999 to 2006]. Available at: <http:// www.mzweb.com.br/brasiltelecom/web/arquivos/BRP_ RA_1999_port.pdf>. Access date: 4 Feb, 2009.

BURNS, Tom.; STALKER, G. The management of innovation. 2. ed. Londres: Tavistock, 1961.

DIMAGGIO, Paul J.; POWELL, Walter W. A gaiola de ferro revisitada: isomorfismo institucional e racionalidade coletiva nos campos organizacionais [The iron cage revisited: institutional isomorfism and collective rationality in organizational fields]. RAE Eletrônica, São Paulo, v. 45, n. 2, abr/jun. 2005. Available at: <http://www.rae.com.br/rae/index.cfm?FuseAction= Arti go $\&$ ID $=3780 \&$ Secao $=$ CLASSICOS $\&$ Volume $=45 \&$ numero $=2 \&$ Ano=2005>. Access date: 4 Feb, 2009.

GVT - Global Village Telecom. A companhia: o mercado brasileiro de telecomunicações [The company: the Brazilian telecommunications market], 2006b. Available at: <http://www. gvt.com.br/ri/>. Access date: 4 Feb, 2009.

GVT - Global Village Telecom. Relação com investidores: 2004 a 2007 [Communication with investors: 2004 to 2007]. Available at: <http://www.gvt.com.br/ri/>. Access date: 4 Feb, 2009. 
HANNAN, Michael. T.; FREEMAN, John. The population ecology of organizations. American Journal of Sociology, v. 82, n. 5, p. 929-964, Mar. 1977.

HAX, Arnoldo C. The strategy concept and process: a pragmatic approach. 2. ed. Upper Saddle River: Prentice Hall, 1996.

HAX, Arnoldo C.; WILDE II, Dean L. The delta project: discovering new sources of profitability in a networked economy. New York: Palgrave, 2001.

HREBINIAK, Lawrence G.; JOYCE, William F. Organizational adaptation: strategic choice and environmental determinism. Administrative Science Quarterly, v. 30, n. 3, p. 336-349, Sep. 1985.

LAKATOS, Eva Maria; MARCONI, Marina de Andrade. Fundamentos de metodologia científica [Scientific methodology fundamentals]. 3. ed. São Paulo: Atlas, 1991.

MINTZBERG, Henry; AHLSTRAND, Bruce; LAMPEL, Joseph. Safári de estratégia. Porto Alegre: Bookman, 2000.

MIRA, Tônia Mansani de. A estratégia de diferenciação no setor de telefonia: um estudo de caso [The differentiation strategy in the telephony sector: a case study]. Dissertação (Mestrado em Engenharia de Produção) - Universidade Federal de Santa Catarina, Florianópolis, 2003. Available at: <http://teses. eps.ufsc.br/defesa/pdf/9860.pdf>. Access date: 4 Feb, 2009.
PFEFFER, Jeffrey.; SALANCIK, Gerald R. The external control of organizations: a resource dependence perspective. New York: Harper \& Row, 1978.

PORTER, Michael E. Estratégia competitiva: Técnicas para análise de indústrias e da concorrência [Competitive strategy: techniques for analyzing industries and competitors]. São Paulo: Campus, 1986.

SCHUMPETER, J. A. The Business Cycle. In Schumpeter, J., The Theory of Economic Development. Cambridge, MA: Harvard University Press. p. 212-255, 1934.

SCOTT, W. R. The adolescence of institutional theory. Administrative Science Quarterly, v. 32, p. 493-511, 1987.

THOMPSON, James D. Organizations in action: social science bases of administrative theory. New York: Jonh Wiley, 1967.

TREACY, Michael, WIERSEMA, Frederik D. A disciplina dos líderes de mercado: escolha seus clientes, direcione seu foco, domine seu mercado [The discipline of market leaders: choose your customers, narrow your focus, dominate your market]. Rio de Janeiro: Rocco, 1995.

WOODWARD, Joan. Industrial organization: theory and practice. American Sociological Review, v. 32, n. 2, p. 313-315, Apr. 1967.

\section{AUTHOR'S BIOGRAPHY}

Fernando Ceragioli holds a Masters degree in Business Administration from Universidade Positivo, in Paraná. His B.Sc. degree is in Electrical Engineering from the Santa Catarina State University (UDESC). For many years he worked for Siemens Telecom responsible to implement fixed networks for operators and to develop bussiness strategies in telecom . Now-a-days, he is at Positivo Informática as Project Manager at Innovation Center responsible for design to cost and tear down. His research interests involve telecom business strategies and value analysis tear-down in computer equipments.

Alexandre Reis Graeml holds a Doctor and a Masters degree in Business Administration (Operations Management and Information Systems Management) from Fundacao Getulio Vargas (FGV-EAESP), in Sao Paulo. His B.Sc. degree is in Electrical Engineering from the Federal University of Technology - Parana (UTFPR). He is currently an associate professor at the Graduate School of Business of Universidade Positivo and at the IS Department of the Federal University of Technology - Parana (UTFPR). He is a Fulbright fellow and his international academic experience includes having been a visiting scholar at the University of California, in Berkeley, and an invited professor at Ecole Supérieure d'Ingénieurs, in Rouen, France, and at Universidad Europea de Madrid, in Spain. His research interests involve the Internet's impact on organizations and our society, supply chain management and internationalization. 